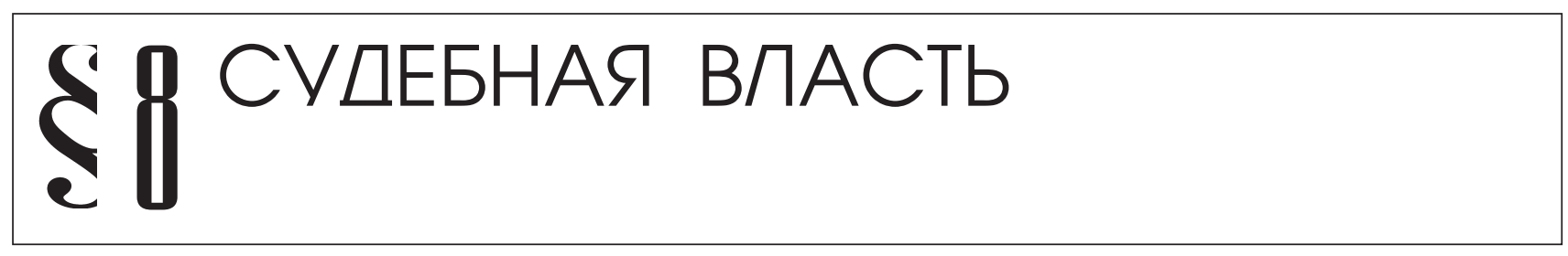

Бозров В.М.

\title{
НЕЗАВИСИМОСТЬ СУДЬИ И ДОКТРИНАЛЬНО-ПРАВОВОЕ ЗАКЛЮЧЕНИЕ УЧЕНОГО
}

\begin{abstract}
Аннотация: Предметом исследования в данной статье стало доктринально-правовое заключение в его соотномении с принципом процессуальной неза-висимости судей. Автором проанализирована проблема юридической сущности доктринально-правового заключения ученого - спещиалиста в конкретной области права, значение этого документа для правильного разрешения уголовного дела. Выявлены и названы факторы, препятствующие широкому внедрению этих заключений в судебную деятельность. В основу работы положены результаты сравнительного анализа практики по данному вопросу Конституционного Суда РФ, а также ряда областных и краевых судов Уральского федерального округа. В ходе исследования автором были использованы методы наблюдения, обобщения, индукции, анализа и синтеза, сравнительно-правовой, активно применялся эмпирический метод. Статья обладает элементами научной новизны, которые заключаются в определении правовой сущности доктринального заключения и обосновании его позитивной роли в разрешении ситуационных проблем, возникающих при отправлении правосудия по уголовным делам.
\end{abstract}

Abstract: This article explores doctrinal legal opinion vis-a-vis the principle of procedural independence of judges. It analyses the problem of the legal essence of the doctrinal-legal opinion of the academic-a specialist in a particular area of law -and the importance of such an opinion in deciding a criminal case correctly. The article identifies factors which prevent the widespread adoption of these opinions in judicial work. It is based on the results of a comparative analysis of the relevant case law of the Russian Constitutional Court, as well as that of a number of regional and provincial courts of the Ural Federal District. The research utilises techniques of observation, generalization, induction, analysis and synthesis, and comparative law as well as the empirical method. The article's academic novelty lies in its determining of the legal nature of doctrinal opinions and its justification for their role in the resolution of situational problems which arise in the administration of criminal justice. Ключевые слова: судья, доктринально-правовое заключение, независимость суда, уголовного судопроизводства, задачи, пренебрежение знаниями, точка зрения ученого, динамичность, законности судопроизводства, судейская независимость

Keywords: judge, doctrinally-legal opinion, independence of the judiciary, criminal justice, problems, disregard of knowledge, expert opinion, dynamism, validity of legal proceedings, judicial independence

Истинная независимость в твоей человеческой необходимости для всех.

Борис Андреев

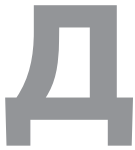

инамичность экономических и социальных процессов на современном этапе развития российского общества повлекла аналогичное явление в праве, а следовательно, и в судебной практике. Не проходит и года, чтобы в тот или иной Кодекс не были внесены существенные изменения. Что же касается текущего законодательства, то и подавно. Неизменным остается лишь стержень правосудия - независимость судей. Значение названного института очевидно, по- этому вряд ли требует теоретического обоснования степень обусловленности качества судебных решений от его гарантированности. К тому же исследованию данного правового феномена посвящено достаточно работ отечественных и зарубежных ученых ${ }^{1}$.

И все же, практика показывает, что независимость как гарантия законности судопроизводства не всегда

\footnotetext{
${ }^{1}$ См. по этому поводу: М.И. Клеандров. Статус судьи. М.2008.
} 
адекватно воспринимается судьями в соответствии с предназначением. Порой избыток амбициозности берет верх над здравым смыслом² ${ }^{2}$ В этой связи нелишне напомнить, что независимость судьи означает свободу от незаконного воздействия в связи с судебным делом, находящимся в его производстве.

Если абстрагироваться от анализа всех видов и направлений судебной деятельности и остановиться лишь на уголовном правосудии, то согласно этому постулату можно утверждать, что в основе своей судейская независимость в уголовном процессе призвана служить формированию судейского усмотрения по оценке доказательств, квалификации преступного деяния и назначению наказания. Это означает, что с одной стороны судья защищен от незаконного воздействия в связи с находящимся в его производстве уголовным делом, a с другой - он напрочь связан волей законодателя. Проще говоря, судья в уголовном судопроизводстве разрешает уголовно-правовой конфликт средствами и способами, названными в законе, и никто сторонний ему в этом не указ.

Казалось бы, сказанное не выходит за пределы банальных истин, которые не требуют напоминания. Однако факты в повседневной жизни говорят об обратном. Порой настойчивость стороны в пользу занимаемой правовой позиции ошибочно расценивается судьями как посягательство на их независимость. Чтобы не быть голословным, сошлюсь на пример из судебной практики.

Выступая в кассационной инстанции, защитник в подтверждение своих доводов огласил рекомендации доктринального заключения ученого по существу проблемы, а затем заявил ходатайство о приобщении этого документа к материалам уголовного дела. В ответ председательствующий саркастически ответил: «Что нам (имея в виду состав суда) теперь разойтись, что ли, если есть заключение ученого». Конечно же, точка зрения ученого не подменяет судей, их решений, и распускать состав суда при заявлении подобных ходатайств не следует, как не следует допускать реплик, пусть даже с целью пресечения мнимого, как в данном случае, посягательства на независимость суда. Никому же в голову не приходит распустить суд после речей сторон. К сожалению, подобные ситуации не редкость.

Автор настоящих строк попытался разобраться в причинах такого негативного восприятия отдельными судьями доктринальных заключений специалистов в области права. Их несколько, но приведу

${ }^{2}$ См. об этом В.И. Телятников. Убеждение судьи. Спб.2004. лишь основные. Первая причина связана с разнобоем в толковании сущности, содержания, пределов, задач и целей судейской независимости, что способствовало формированию в сознании части судейского корпуса вульгарного представления о принципе независимости судьи, уподобив его некой правоприменительной вольнице, даруемой Указом Президента при назначении на должность. В результате советы более опытных коллег, а порой и рекомендации руководителей судов и ученых воспринимаются ими как покушение на самостоятельность в принятии того или иного процессуального решения по находящемуся в производстве делу.

Разумеется, и рекомендации руководителей, и коллегиальные обсуждения возникших по рассматриваемому делу вопросов не должны уподобляться инструктажам и советам императивного характера. В принятии решения судья независим. Однако законность и обоснованность этого решения должны быть обеспечены квалификацией судьи, включающей не только знание закона, но и теорию, и судебную практику его применения. В противном случае ошибка неизбежна. Не случайно претендент на должность судьи по данному поводу подвергается соответствующим испытаниям, а после назначения на должность допускается к отправлению правосудия по завершении курса переподготовки по основным отраслям права в объеме не менее 500 часов. Если к этому добавить знания, получаемые в вузе, и приобретенный опыт юридической деятельности (не менее 5 лет), то можно утверждать о высоком уровне профессиональной подготовки судей. Однако, как говаривал известный литературный персонаж, «объять необъятное невозможно», поэтому судьи фактически не в состоянии обладать тем объемом знаний во всех отраслях права, которым владеет ученый, занимающийся проблематикой конкретной отрасли права. Именно по этой причине Конституционный Суд РФ и суды ряда регионов России признали полезной практику привлечения ученых к консультативному процессу по конкретным делам ${ }^{3}$.

В этом смысле не стали исключением и суды Свердловской области. Например, гражданин «N» подвергался уголовному преследованию за нарушение техники безопасности при эксплуатации аттракциона. Из представленных в суд материалов усматривалось, что «N» зарегистрирован в одном городе, но на время следствия остановился в гостинице другого города по месту нахождения следственного органа. За границей у «N»

\footnotetext{
${ }^{3}$ Об этом подробно: Эксархопуло А. А. Специальные познания и их
} применение в исследовании материалов уголовного дела. М. 2005. 
DOI: 10.7256/1811-9018.2013.11.10046

При цитировании этой статьи сноска на dоі обязательна

\section{Право и политика $11(166) \cdot 2013$}

имелись близкие родственники. Первый факт суд расценил как отсутствие у обвиняемого постоянного места жительства, а второй - как предпосылку к тому, что он может скрыться от органов предварительного расследования, и на этом основании избрал в отношении «N» в качестве меры пресечения заключение под стражу. Принятию такого ошибочного решения способствовала противоречивая судебная практика разрешения подобных ситуаций. Вместе с жалобой на указанное решение суда адвокат представил в кассационную инстанцию доктринально-правовое заключение ученого, в котором обосновывалось несоответствие принятого судом решения п.п. 1 и 4 ст. 108 УПК РФ. Рассмотрев жалобу адвоката и приобщив правовое заключение ученого к материалам дела, суд кассационной инстанции изменил «N» меру пресечения на менее строгую.

Учитывая требование о соблюдении тайны совещательной комнаты, можно предположить, что мнение профессора-специалиста в области уголовного процесса не осталось без внимания судей.

Вторым основным источником, сформировавшим нигилистическое отношение некоторых судей к правовым заключениям ученых, является постановление Пленума Верховного Суда СССР № 1 от 16 марта 1971 года «О судебной экспертизе по уголовным делам», в п. 11 которого подчеркивалось, что суды не должны допускать постановку перед экспертом вопросов, не входящих в его компетенцию (например, имело ли место хищение либо недостача, убийство или самоубийство) ${ }^{4}$. Как верно заметил профессор А.А. Эксархопуло, поддержав эту позицию Верховного Суда, большинство ученых истолковали понятие «правовых вопросов» как синоним формулы «виновен - не виновен». Судебная практика отнеслась к рекомендациям Пленума в том же ключе и распространила их на все случаи жизни как запрет на правовую экспертизу5. Между тем здесь необходима следующая оговорка: во-первых, такого табу нет ни в УПК РСФСР, ни в современном уголовно-процессуальном законодательстве, во-вторых, привлекаемые к оказанию помощи в толковании правовых вопросов ученые экспертами либо специалистами в смысле ст.ст. 57 и 58 УПК РФ не являются, поскольку они не обладают таким процессуальным статусом. А значит, выводы, содержащиеся в доктринальном правовом заключении, доказательством по уголовному делу быть не могут. Поэтому несогласие суда с мнением ученого не требует опровержения в процессуальных документах.

То есть доктринальное заключение специалиста в области права - не более чем точка зрения лица, обладающего углубленными знаниями в части разрешения возникшей правоприменительной проблемы по конкретному уголовному делу. Таким образом, рассматривать его надо как своеобразную «нить Ариадны» в решении ситуационной правоприменительной задачи. Следовательно, пренебрежение знаниями, содержащимися в заключении ученого, означает осознанный отказ судьи от дополнительной возможности воспользоваться данными науки во избежание судебной ошибки.

Разумеется, точка зрения ученого - не панацея от ошибки и тем более не альтернатива приговору или иному решению суда, но и не способ незаконного воздействия на суд. Здоровое воображение вряд ли позволит заявить, что специалист, например, в вопросах уголовного права, выразив свое компетентное мнение относительно квалификации преступного деяния по конкретному делу, тем самым подменяет суд. И судьям как никем другим должно быть известно, что право предлагать решение правовых вопросов и право принимать правовые решения - понятия не тождественные.

\section{Библиография:}

1. Клеандров М.И. Статус судьи. М., 2008.

2. Телятников В.И. Убеждение судьи. СПб., 2004.

3. Эксархопуло А.А. Специальные познания и их применение в исследовании материалов уголовного дела. М., 2005.

\section{References (transliteration):}

1. Kleandrov M.I. Status sud'i. M., 2008.

2. Telyatnikov V.I. Ubezhdenie sud'i. SPb., 2004.

3. Eksarkhopulo A.A. Spetsial'nye poznaniya i ikh primenenie $\mathrm{v}$ issledovanii materialov ugolovnogo dela. M., 2005.

\footnotetext{
${ }^{4}$ Сборник постановлений Пленума Верховного Суда СССР. 19241977 г.г. ч..2. М. 1978. С.339.

${ }^{5}$ См. об этом: Эксархопуло А. А. Та же монография, стр. 66-67.
} 